Trivent Publishing

(C) The Authors, 2016

Available online at http://trivent-publishing.eu/

Series: Philosophy, Communication, Media Sciences

Volume: Communication Today: An Overview from Online Journalism to Applied Philosophy

\title{
Transversal Competences or How to Learn Differently
}

\author{
Mariana Crașovan \\ Science of Education Department, West University of Timisoara, Romania \\ mariana.crasovan@e-uvt.ro
}

\begin{abstract}
In this article, we try to answer a few critical questions: Why is developing the competences of learners so important and why should teaching, learning and assessment be grounded in a competence-based approach? How was such a curriculum based on transversal competences implemented at the West University of Timisoara (Romania)? In a dynamic and problem-based society, education systems focus more and more on helping learners develop a wide variety of competences to cope with our complex world. On a European level, different frameworks of competences were established which are meant to be developed in higher education. In relation to these competences, specialists invoke transversal competences, skills for life, such as: critical thinking, creativity, taking the initiative, problem solving, risk assessment, decision taking, constructive emotional management, cooperation and/or working in a team.

From the 2014-2015 academic year onwards, the West University of Timisoara has implemented a system which allows students to choose three subjects from different specializations in order to develop transversal competences. In this paper, we analyze the way of implementation, elements of the course syllabus correlated with transversal competences and the skills developed through those subjects since its inception.
\end{abstract}

\section{Keywords}

Curriculum; transversal competences; subject; syllabus; objectives; learning content; assessment.

This is an Open Access article distributed in accordance with the Creative Commons Attribution Non Commercial (CC-BYNC-ND 4.0) license, which permits others to copy or share the article, provided original work is properly cited and that this is not done for commercial purposes. Users may not remix, transform, or build upon the material and may not distribute the modified material (http://creativecommons.org/licenses/by-nc/4.0/)

DOI: 10.22618/TP.PCMS.20164.349016 


\section{Introduction}

One of the main concerns of universities is to make the curricular offer more attractive and efficient so that future graduates could better face the ever-changing world. Until recently, universities prepared students in terms of "one life-one career," but in the current context we can speak in terms of "one life-many careers."

Now more than ever, the relevance of academic studies and their usefulness (that is, the subjects' worth being taught and learnt) is a challenge for which universities should try to offer solutions. Knowledge by itself is not enough anymore; it needs to be applied and used in different life-contexts. Meanwhile, we must consider the fact that students have changed because of the easy access to information and the use of new technologies. Learning does not occur strictly in the classroom or closely related to the educator. What we teach? How we teach? What are the objectives of the course? How we can better organize the learning experiences in order for them to be useful and relevant? these are all questions on which every educator should reflect.

A curriculum based on competencies is also a requirement that Romanian universities must put into practice. Beyond the key competencies and the specific competencies for a particular field of study, specialists discuss all the more about transversal competencies, skills which are absolutely necessary on a dynamic and constantly evolving labour market. The West University of Timisoara had the initiative to introduce this opportunity to students, regardless of their specialisations, in order to complete their specific education in a certain field with a set of transversal competencies.

\section{How to develop transversal competences - a case study}

Beginning in the 2014-2015 academic year, the West University of Timisoara implemented "The regulation on the development of curricula (study-plans) for study programs in West University" (bachelor's degree). The main idea behind this regulation was that students can broaden their training in their chosen field by means of a flexible academic journey with multiple options. Thus, for the third, fourth and fifth semester students have the option of choosing one complementary discipline in order to develop transversal competencies. These are chosen from a set of disciplines offered faculties outside the student's major. To ensure that all study-plans were compatible, these subjects were standardized to feature: one-hour lecture, one-hour seminar and two transferable European credits.

University professors have the option to propose such subjects either in the form of curriculum that already exists in a different specialization or as a new discipline entirely.

Educators reacted to this Regulation differently; some were sceptical while others were enthusiastic and wished to be involved. This is reflected in the evolution of the total number of complementary disciplines offering transversal competences: from 54 in the 2014-2015 academic year to 152 in the 2015-2016 academic year. The 152 subjects are distributed among faculties as follows:

Table 1: The distribution of disciplines whose faculty initiated new courses on transversal competences: ${ }^{1}$

\begin{tabular}{|l|c|c|}
\hline \multicolumn{1}{|c|}{ Faculty } & Number of courses & Percentage \\
\hline Arts and Design & 8 & $5.26 \%$ \\
\hline Chemistry, Biology and Geography & 12 & $7.89 \%$ \\
\hline Law & 6 & $3.94 \%$ \\
\hline Economics and Business Administration & 36 & $23.68 \%$ \\
\hline
\end{tabular}

1 S. Sava, M. Crașovan, "Conceptualizarea pedagogică a demersului didactic, ca premisă a calității procesului educațional în învățământul superior" [The pedagogical conceptualization of teaching, as a premise for the quality of the educational process in higher education], in Calitatea educației-Învățare-Dezvoltare umană [The quality of education - learning - human development], ed. D. Potolea, F. Tacea (Bucharest: Editura Ars Docendi, 2015). 


\begin{tabular}{|l|c|c|}
\hline Physical Education and Sport & 5 & $3.28 \%$ \\
\hline Physics & 8 & $5.28 \%$ \\
\hline Letters, History and Theology & 33 & $21.71 \%$ \\
\hline Mathematics and Informatics & 8 & $5.26 \%$ \\
\hline Music and Theatre & 2 & $1.31 \%$ \\
\hline Sociology and Psychology & 16 & $10.52 \%$ \\
\hline $\begin{array}{l}\text { Political Sciences, Philosophy and Communication } \\
\text { Sciences }\end{array}$ & 18 & $11.84 \%$ \\
\hline
\end{tabular}

The number of subjects offered is closely related to the size of the faculty as well as to the level of involvement on the part of the educators. Most of the subjects are offered from the field of Economics, followed by disciplines related to philology (i.e. the Faculty of Letters, History and Theology) and Political Science. The least number of new subjects on this model are offered by the Faculties of Music and Theatre, Physical Education and Sport and Law. All disciplines are from the curricular offerings of different study programs; no discipline was designed for the specific purpose of developing transversal competences.

The courses which received the highest number students enrolling are the following: The health of human reproduction (Faculty of Chemistry, Biology, Geography-210 students), The science of eating healthy (Faculty of Chemistry, Biology, Geography-182 students), First aid (Faculty of Physical Education and Sport-160 students), Psycho-sexology (Faculty of Sociology and Psychology-94 students), Portuguese language (Faculty of Letters, History and Theology-87 students), American cinematography (Faculty of Letters, History and Theology-79 students), Cultural geography and cultural tourism (Faculty of Chemistry, Biology and Geography-78 students) and finally History of universe and cosmology (Faculty of Physics-75 students). Likewise, there were some courses that only a few students chose to enrol in.

At the university level, a framework of transversal competences that the university wants to develop in its students has not been formally established. As such, each teacher has transposed various and diverse competencies in the subject syllabus, leading to many possible redundant or nonintegrated skills being taught.

\section{The analysis of the course syllabus}

In this study, we intend to analyze the curricular offer of the current academic year (2015-2016). All curricular documents are posted on West University of Timisoara web-site (www.dct.uvt.ro); these include, but are not limited to, the course syllabus, a brief presentation of the various disciplines and the teachers' activities (i.e. a short version curriculum vitae).

There are two levels of analysis of the curricular offer we wish to highlight here. The first level is an analysis of curriculum documents, namely the course syllabus; the second level would be an analysis of the educational process in terms of teaching activities as well as the students' perspectives on learning activities. In this analysis, we choose the first level, focusing primarily on analysing the courses' syllabus.

The course syllabus is an official document which establishes the connection between student and instructor from the beginning of the course onward. It is a real "learning contract", which reflects the teaching philosophy of the instructor and their attitude towards students in terms of what they will learn. From the students' point of view, the course syllabus offers information regarding what he/she is going to learn, the workload, the learning outcomes, responsibilities for the duration of the course and the methods and procedures for how their work will be assessed. We can confidently say that the course syllabus is a valuable learning tool for students, helping them find answers to the following

\footnotetext{
${ }^{2}$ J. Grunert, The course syllabus: A learning centerd approach (Bolton, MA: Anker Publishing Company Inc,
} 1997), 16. 
question: "How can this course help me from an intellectual and practical point of view?" The contact between the student and the course syllabus contributes to how the student views the subject, an attitude that will be consolidated later vis-à-vis the direct relationship with teacher during specific teaching-learning situations.

In The course syllabus: A learning-centred approach, $\mathrm{J}$. Grunert ${ }^{3}$ states that the characteristics of a well-written and well-developed syllabus includes:

- Describing the instructor's beliefs about teaching, learning and assessment;

- Setting a contract and rapport between students and teachers;

- Familiarizing the student with the course structure;

- Offering information about how this course is integrated into the general context of the curriculum;

- Describing the learning resources available;

- Including materials which support learning outside the classroom".

In addition to the aforementioned characteristics, we could add that every subject syllabus should also be flexible, negotiable, clear, and explicit for both teachers and for students.

In this study, we analyse how a course's syllabus is developed, how the curriculum is approached, to what extent teachers working in higher education are familiar with didactic practices and to what extent the offered subjects really are complementary subjects that develop transversal competences. In order to do this, we analyse the main elements of a course's syllabus: the correlation between European transferable credits and the students' workload, the main types of activities, specific competences and transversal competences of the course, the course objectives, the way in which the content of the course is developed in the course and seminar activities, the didactical strategies used, bibliographic resources and methods of assessment.

Correlation between credits and workload: based on the fact that each discipline is allocated two credits, the total volume of time that must be distributed is 50 hours. 28 hours are allocated to face-toface activities (i.e. courses and seminars), and the remaining 22 hours are allocated to activities such as reading different books or articles or preparing of research papers.

As we mentioned earlier, some of those disciplines are part of the curricular offer of different study programs. Some instructors choose the same course syllabus as those from their main area of specialisation without adapting it, even when the number of credits and the teaching hours are different. Analysing patterns of the course syllabus, we notice that $86 \%$ of them do not correct errors between the number of credits and the workload for students. This aspect reflects the lack of coherence in designing different tasks for different subjects which could easily cause confusion among the students.

Transversal competences intended for development: competence is a pedagogical concept that is both somewhat controversial and not clearly internalised or understood by university professors. An educational process based on competencies is supposed "to bring the real world into the classroom, to design learning situations focused on problem solving, to learn by collaboration, to use new technology and to focus the didactic process on the learner and the learning process."

The educational literature contains a variety of terminology used to express the complex reality of competences (more or less). We encounter both notions of transversal competences and also "nonacademic skills," "skills for the XXI century," "learning for the $21^{\text {st }}$ century," "cross-curricular skills," "non-cognitive skills," "skills for life" or "generic skills."4

Claudiu Langa ${ }^{5}$ defines transversal competences as "...those skills which transcend a certain field, nuance and strengthen the professional competence." Transversal competences are subject-

\footnotetext{
${ }^{3}$ Ibidem, 14-19.

${ }^{4}$ ERI-NET, UNESCO, Transversal competencies in education policies and practice (Regional Synthesis Report, 2015).

${ }^{5} \mathrm{C}$. Langa, "The contribution of transversal competences to the training of the educational sciences specialists," Procedia-Social and Behavioural Sciences 180 (2015): 7-12.
} 
independent and cross-curricular. They are related to the better management of one's own learning as well as social and interpersonal relations and communication; transversal competences reflect the general shift in emphasis from teaching to learning. ${ }^{6}$

Regarding the integration of the transversal competences into curriculum, Gordon et al. identify three modalities:
A. by adding transversal competencies to the already existing curriculum as new subjects or as new content within traditional subjects;
B. by integrating transversal competencies as cross-curricular competencies that underpin all school subjects or;
C. by making transversal competencies part of a new curriculum in which the traditional structure of school subjects is transformed and schools are regarded as learning organisations. $^{7}$

Transversal competences are described by $\mathrm{UNESCO}^{8}$ as being organized according to five domains: critical and innovative thinking (creativity, entrepreneurship, resourcefulness, application skills, reflective thinking, reasoned decision-making), interpersonal skills (communication skills, organizational skills, teamwork, collaboration, sociability, collegiality, empathy, compassion), intrapersonal skills (self-discipline, the ability to learn independently, flexibility and adaptability, selfawareness, perseverance, self-motivation, compassion, integrity, risk-taking, self-respect), global citizenship (awareness, tolerance, openness, responsibility, respect for diversity, ethical understanding, intercultural understanding, ability to resolve conflicts, democratic participation, conflict resolution, respect for the environment, rationale identity, sense of belonging) and media and information literacy (the ability to locate and access information through ICT, media, libraries and archives, to express and communicate ideas through ICT, use media and ICT to participate in democratic process, ability to analyze and evaluate media content). The distinction between subject-based and transversal competences is not very clear. ${ }^{9}$

On one hand, we have observed that the approach usually chosen by educators is to integrate transversal competencies within the study of different subjects. There are specialized disciplines which are strictly related to certain specializations and are thus less complementary with others. The freedom of choice that students have can sometimes be unfavourable to them in terms of competencies specific to certain specialization which are complementary neither to their training nor their education as a specialist within a certain field.

On the other hand, different specialisations within some of the disciplines as part of could require certain prerequisites that students from those specialisations could already have. The question that arises from this point is: How could we develop transversal competences for students who have not yet studied these disciplines?

Analyzing transversal competences specified in the course's syllabus, we can observe faulty expressions, inaccurate or generic competences unrelated to the course or undefined skills lacking clarity. Some examples of this: "this course provides a trans-disciplinary approach ... giving the possibility to charge expressions of multiculturalism, cultural and artistic diversity," "assuming the capacity to organise a session presenting the results obtained in different ethnographic projects," "fulfilling complex professional tasks effectively," "displaying a responsible attitude towards scientific and didactical fields," "respecting the work rules," "implementation strategies about

\footnotetext{
${ }^{6}$ European Commission/EACEA/Eurydice, Developing Key Competences at School in Europe: Challenges and Opportunities for Policy, Eurydice Report (Luxembourg: Publications Office of the European Union, 2012).

${ }^{7}$ J. Gordon, G. Halasz, M. Krawczyk, T. Leney, A. Michel, D. Pepper et al., Key Competences in Europe: Opening Doors for Lifelong learners across the school curriculum and teacher education (Warsaw, 2009).

${ }^{8}$ ERI-NET, UNESCO, "Transversal competencies" (see footnote 4).

${ }^{9} \mathrm{M}$. Amadio, "A rapid assessment of curricula for general education focusing on cross-curricular themes and generic competences or skills", Paper commissioned for the EFA Global Monitoring Report 2013/4, Teaching and learning: Achieving quality for all (2013).
} 
punctuality, reliability and personal responsibility," "awareness of its own creative potential and personal and professional development on an ongoing basis."

Among transversal competences genuinely pursued by those disciplines, those mentioned most frequently are those relating to oral/verbal and written communication, reflective thinking, teamwork, application skills and ability to learn independently. We were surprised to notice that very few competencies mention media and information literacy or global citizenship.

The objectives: are the finalities of the course, showing which main behaviours students develop by attending the course in question. We note that between the specific competences and subject-course objectives there are not links, not links to each other. Much of the behavioural objectives aimed primarily at the acquisition of notions and concepts linked to receiving information; few behavioural objectives aimed at higher goals such as analysis, synthesis, or evaluation. Various objectives consist of words such as "understanding," "knowledge," "acquisition," and "assimilation." This aspect, which implicitly reflects the vision of teachers, is strengthened by using mainly a small range of methods which usually involve interactions with the whole class and little student involvement or participation. On the other hand, we noticed a number of defective expressions of objectives or even expressions that do not reflect the objectives, such as: "development of a multidisciplinary vision," "bibliographical investigation," "searching on the internet."

The content and teaching strategies: are generally expressed in the form of titles, most often differentiated by course and seminar activities. In a few cases, the content covered in the seminar activities are not listed specifically, but instead it is mentioned that the seminar will delve into or apply themes studied during the courses. Only in rare cases do the educators clearly delineate content depending on the amount of time available, i.e. 14 hours for courses and 14 hours for seminars. The time allocated to study different themes or the amount of time necessary for certain themes are usually not specified.

By analysing the teaching strategies, we can see that these concerns are not given due consideration in the syllabus; they are only mentioned quite succinctly. Some defective expressions encountered include: "projections," "talk," "power-point presentation." We also note that the syllabus does not include a variety of strategies, but only include the most common didactic methods: lecture, explanation, demonstration, case studies and problem solving.

The evaluation methods: from our analysis, we were shocked to notice that most students are evaluated on written works or presenting certain topics. When implementing a competence-based education, the methods of evaluation and related tasks must put students in a position to actively do something so that the competencies can be assessed in real contexts and situations. Written assessment methods still dominate the evaluation approach too much, to the detriment of oral and practical work. In all probability, this is due to the relatively large number of students working with the teacher which implies an evaluation too long for oral or practical methods. Another noteworthy aspect is how the assessment criteria are presented. We highlight terms that are too general and vague, with no concrete specification. In those cases, the terminology is practically useless for students, as these instructions are supposed to highlight what is sought through evaluation and which aspects should be the main pursuit. Expressions like "assessment of the ability of analysis and synthesis," "thematic relevance," "active presentations," "developing a trans-disciplinary essay" are simply not correct expressions of the evaluation criteria.

The bibliographic resources: are generally shown separately for lectures and seminars. Analysing the syllabus on this component highlights the absence of current bibliographic resources; most of the bibliographic resources mentioned (even 20), are overwhelmingly books or monographs. The chapter(s) to be completed are only mention in very few cases. Giving students 15-20 books without mentioning pages, chapters to study and with no immediate relevance with the themes covered in the lectures or seminars is a highly inefficient approach. Furthermore, these bibliographies rarely include articles or webography. A minimum or compulsory bibliography for all students is not distinguished 
from an extensive bibliography for those who want to study more. We believe students need guidance in the reading process: by guiding them through the reading process, offering some new and relevant books or articles and by specifying the chapters to be completed for which theme. While we concede that this is a relatively large organizational effort for the instructor, it is nonetheless absolutely necessary to guide the students' learning process.

In the analysed course syllabus, we underline the focus especially on contents and inventories of themes and emphasize less focus on results which are reinforced by some inconsistency between the competencies and the objectives and goals proposed in the regulations.

\section{Conclusions}

The initiative described in this study is a commendable one that offers many benefits for both teachers and students. Instructors have the opportunity to work with students coming from diverse specializations, different backgrounds and needs and with diverse learning potentials. From the students' perspective, this initiative is an opportunity to develop a set of transversal competencies (which are vital in the current labour market), to interact and learn together with students from different specializations, to customize their own learning paths and training, to choose according to their needs, interests and skills, and to encounter diverse approaches of teaching, learning and assessment, different from those previously used.

A course syllabus represents a useful document for the review committee as it forms proper evidence of a faculty's effectiveness, both in terms of teaching abilities ("during promotion and tenure reviews, syllabi may be examined as evidence of the instructor's teaching quality" ${ }^{10}$ ), and also of scientific skills or attitude towards learners ("a syllabus can provide evidence of a teacher's mastery of his field and of his responsibility towards his students"11). ${ }^{12}$

Besides the aforementioned advantages, we must not lose sight of the fact that this initiative should be improved and streamlined, in order to realize the true purpose for which it was proposed. Our suggestions for improving the implementation of the procedures which develop transversal competences are:

- Establishing a framework of transversal competences that the university wants their students to develop through complementary disciplines, through consultation of teachers, students and employers.

- Linking complementary disciplines with those competences in order to cover the whole range of competences agreed upon. Thus, the university ensures that all proposed competencies are developed by different disciplines, eliminating redundant elements or omissions. This would be much clearer for students who could plan their elective courses knowingly and effectively.

- Consultation between the curriculum commissions and educators in order to streamline which courses on the curricular offer are truly complementary and develop transversal competences. This would eliminate a number of initiatives which are complementary with restricted specializations or disciplines that require prior possession of prerequisites necessary for understanding the new course.

- Training instructors on academic and curriculum components, namely the curricular conceptualizations: terminology, relationship between concepts, ways of implementation.

- Informing students how to choose wisely: organizing some information sessions to explain the rules, disciplines organizing a presentation by all teachers of their curricular offerings.

- Training teachers working in higher education on the adult education component, highlighting ways to effectively interact with new generations of students. Teachers work with different students, different learning styles, previous, relatively heterogeneous training and/or different learning potential. Teaching involves not only lectures, but also a good conception, design and implementation of

${ }^{10}$ P.E. Doolittle, D.L. Lusk, "The effects of institutional classification and gender on faculty inclusion of syllabus components." Journal of the Scholarship of Teaching and Learning 7(2) (2007): 63.

${ }_{11}$ J. Leibow, "Evaluating Plan: Evaluating Course Syllabi for Undergraduate Courses at SDSU," Dept. Educational Technology, San Diego University (2003), 6.

${ }^{12}$ L. Leduc, "Using the course syllabus to document the quality of teaching and identifying its most useful items according to the students," European Quality Assurance Forum (2011). 
teaching approach using new paradigms. Centring the teaching approach on facilitating the students learning, facilitating their own discoveries and meanings and their own experiential transfers is of utmost importance.

A limitation of this study would be that it focuses strictly on curriculum documents without taking into account the experiences of teachers who supported such courses and students. It seems appropriate in the future to initiate and carry out research for teachers to assess their own didactic experiences, the interaction with students from different specializations. This research must also focus on students, as direct beneficiaries to assess learning experiences, to assess their effectiveness, the development of transversal competences and to identify ways to streamline the curricular offer the benefit for all: students, teachers, university and (why not?) subsequently the labour market.

\section{References}

Amadio, M. "A rapid assessment of curricula for general education focusing on cross-curricular themes and generic competences or skills." Paper commissioned for the EFA Global Monitoring Report 2013/4, Teaching and learning: Achieving quality for all (2013).

Doolittle, P. E., Lusk, D. L. "The effects of institutional classification and gender on faculty inclusion of syllabus components", Journal of the Scholarship of Teaching and Learning 7(2) (2007): 63.

EACEA/Eurydice, Developing Key Competences at School in Europe: Challenges and Opportunities for Policy. Eurydice Report, Luxembourg: Publications Office of the European Union, 2012.

ERI-NET, UNESCO. Transversal competencies in education policies and practice. Regional Synthesis Report, 2015.

Gordon, J., Halasz, G., Krawczyk, M., Leney, T., Michel, A., Pepper, D. et al. Key Competences in Europe: Opening Doors for Lifelong learners across the school curriculum and teacher education (Warsaw, 2009).

Grunert, J. The course syllabus: A learning centerd approach. Bolton, MA: Anker Publishing Company Inc, 1997.

Langa, C. "The contribution of transversal competences to the training of the educational sciences specialists." Procedia-Social and Behavioural Sciences 180 (2015): 7-12.

Leduc, L. "Using the course syllabus to document the quality of teaching and identifying its most useful items according to the students." European Quality Assurance Forum (2015).

Leibow, J. Evaluating Plan: Evaluating Course Syllabi for Undergraduate Courses at SDSU. Dept. Educational Technology. San Diego University, 2003.

Regulament privitor la elaborarea planurilor de invatamant pentru programele de studii in UVT (nivel licenta) [Procedure of developing the study plan in West University of Timisoara] www.uvt.ro (accessed August 09, 2016).

Sava, S., Crașovan, M. "Conceptualizarea pedagogică a demersului didactic, ca premisă a calității procesului educațional în învățământul superior" [The pedagogical conceptualization of teaching, as a premise for the quality of the educational process in higher education]. In Calitatea educațieiInvățare-Dezvoltare umană [The quality of education - learning - human development], ed. Potolea D. and Tacea F. Bucharest: Editura Ars Docendi, 2015. 